\title{
Factors Determining the Adoption of Strategies Used by Smallholder Farmers to Cope with Climate Variability in the Eastern Free State, South Africa
}

\author{
Lindumusa Myeni ${ }^{1, *}$ and Mokhele Edmond Moeletsi ${ }^{1,2}$ (1) \\ 1 Agricultural Research Council-Institute for Soil, Climate and Water, Private Bag X79, \\ Pretoria 0001, South Africa; MoeletsiM@arc.agric.za \\ 2 Risks and Vulnerability Assessment Centre, University of Limpopo, Private Bag X1106, \\ Sovenga 0727, South Africa \\ * Correspondence: MyeniL@arc.agric.za
}

Received: 17 August 2020; Accepted: 14 September 2020; Published: 16 September 2020

\begin{abstract}
This study was undertaken to understand the smallholder farmer's perception of the effects of climate variability, their adaptation strategies to cope with climate variability and factors determining the adoption of their adaptation strategies in the eastern Free State Province of South Africa. Adaptation strategies were grouped into two categories, i.e., traditional adaptation strategies and scientific adaptation strategies. Traditional adaptation strategies consisted of practices that require minimal technical expertise and less external inputs such as changing from crops to livestock, crop diversification, increasing land under production, changing crop type and water harvesting. Scientific adaptation strategies consisted of practices that require additional external inputs, labour, and some level of technical expertise such as changing crop variety, improving soil fertility and soil conservation. Data were collected from 391 smallholder farmers using a structured household questionnaire and were verified through focus group discussion meetings with key informants. Data were analysed using the descriptive statistics, frequency analysis and a binary logistic model. Results indicated that the majority of smallholder farmers perceived that climate change had triggered food-related impacts in the study area and had adopted at least one adaptation strategy. This study showed that awareness and knowledge were the key factors that determined the adoption of traditional adaptation strategies in the study area. The adoption of scientific adaptation strategies was additionally determined by the availability of external financial investments. It is recommended that the promotion of traditional practices should focus on raising awareness of climate change and adaptation strategies while the promotion of scientific practices additionally requires the provision and accessibility of financial institutional support and incentives.
\end{abstract}

Keywords: awareness of climate change; climate information; scientific adaptation strategies; traditional adaptation strategies

\section{Introduction}

Agriculture is widely recognized as the vehicle through which rural development, food and nutrient security can be attained in Africa [1-3]. However, agricultural production is highly sensitive to climate change/variability as the result of its high reliance on climate variables such as rainfall, temperature, wind speed and relative humidity [4-6]. Furthermore, the majority of the African smallholder farmers farm in soils of low fertility, have inadequate farm equipment and limited income, have restricted access to climate information and often lack basic agronomic knowledge, thus making them highly vulnerable to the negative effects of climate variability $[7,8]$. 
In Africa, an increase in air temperatures, the high variability of rainfall onsets and amounts, prolonged dry spells, and the frequent occurrence of intensified extreme weather hazards such as floods and droughts are expected as a result of predicted climate change [9-11]. Such changes are already affecting agricultural production with evidence of crop failure, food insecurity, death of livestock as well as outbreaks of pests and diseases being reported in recent years in this region $[9,10,12]$. Consequently, climate change and variability are already affecting and will continue to threaten the livelihood and food security of the majority of the smallholder farmers in Africa due to their vast reliance on rainfed agricultural production and often having restricted adaptation capacity as a result of financial, resources and knowledge constraints [6,9,13-15].

The need to limit the adverse effects of climate-related risks on agriculture production through effective adaptation and mitigation strategies is becoming more urgent to support sustainable agricultural productivity and to improve food security for African smallholder farmers [9,10,15-17]. Several adaptation strategies have been developed, validated, and recommended to cope with the effects of climate variability on rainfed crop production $[8,18,19]$. These can be broadly grouped into two categories, i.e., traditional adaptation strategies and scientific adaptation strategies. Traditional adaptation strategies consist of simple practices that do not require additional inputs such as labour, hybrid seeds, fertilizers and technical farm implements or intensive-technical skills such as changing planting dates, changing crop types, crop diversification, rainwater harvesting, increasing land under crop production, or changing from crops to livestock $[18,20,21]$. Scientific adaptation strategies consist of more complex practices that are knowledge-intensive and require additional external inputs and labour such as changing crop variety, improving soil fertility and soil conservation [18,20-22]. Despite the well-documented effectiveness and feasibility of the traditional strategies to cope with climate change in resource-constrained rural communities, adoption remains low in Africa mainly due to the lack of awareness of climate change and effective adaptation strategies $[18,20,21]$. On the other hand, the low adoption of scientific strategies to cope with climate change is often attributed to low levels of education, age, low income, lack of awareness of climate change and adaptation strategies, lack of labour, poor access to credit and extension services $[8,18,19,23]$. Previous studies on farmers' perceptions of climate change across the African continent indicated that the majority of smallholder farmers often perceive the variability of onsets, rainfall amount and duration of the rainy season as well as the frequent occurrence of droughts and incidences of pests and diseases to be the major weather-induced risks attributed to climate change that affect their agricultural production [24-26]. Furthermore, these studies indicated that availability of labour, gender, farming experience, income, level of education, land ownership, access to extension services, credit and markets were often the main determinants of the choices of adaptation strategies used by smallholder farmers across the African continent $[5,18,19,27-29]$. This previous research showed that farmers' perceptions of climate change and their relative adaptation strategies are local-specific as a result of differences in local policies, availability of infrastructure, resources, political and cultural ideologies as well as access to climate information [5,6,30-32].

Given the wide range of cultural ideologies and agro-climatic conditions in South Africa, knowledge of the farmers' perceptions and their adaptation strategies across the country is crucial for the development and implementation of effective and informed policies to enhance sustainable agricultural productivity [33]. Although a few early studies were undertaken to understand farmers' perceptions and their relative adaptation strategies to cope with climate variability in South Africa $[8,28,33,34]$, these did not investigate the determinants of the choices of adaptation strategies used by smallholder farmers in the country. The understanding of those determinants is a prerequisite for the development of informed and effective interventions to build climate-resilient rural communities, not only in the case of the study area but also in other communities facing similar socio-economic challenges [19]. Furthermore, amongst the studies on determinants of the choice of adaptation strategies that have been conducted across the African continent, very few have considered the differences between traditional and scientific adaptation strategies [18-21]. Therefore, the determinants and the challenges limiting 
smallholder farmers in Africa from adopting traditional adaptation strategies have not been well investigated [18]. However, traditional adaptation strategies have the potential to be adopted easily by resource-constrained smallholder farmers despite their serious socio-economic and institutional challenges that still need to be solved at a national level. Consequently, the improved understanding of the challenges preventing smallholder farmers from adopting traditional adaptation strategies is imperative for the development of informed and effective interventions to enhance climate-resilience of these farmers with little effort and external resources. Therefore, this study was undertaken to understand the smallholder farmer's perception of the effects of climate change on their crop production, their adaptation strategies and factors determining the adoption of their adaptation strategies in the eastern Free State Province of South Africa. Firstly, we determine their perception of the effects of climate change on agricultural production. Secondly, we identify the adaptation strategies they used and the extent of their adoption. Thirdly, we identify the factors determining the adoption of those adaptation strategies. Finally, we recommend relevant approaches to increase the climate-resilience of smallholder farmers in the study area.

\section{Materials and Methods}

\subsection{Study Site Description}

The study was carried out in the different villages of the Harrismith and Phuthaditjhaba towns that are located in the Maluti-a-Phofung municipality within the Thabo Mofutsanyana district in the eastern part of the Free State Province of South Africa (Figure 1). Free State is located between latitudes $26.6^{\circ} \mathrm{S}$ and $30.7^{\circ} \mathrm{S}$ and between longitudes $24.3^{\circ} \mathrm{E}$ and $29.8^{\circ} \mathrm{E}$ and is the third of the largest provinces in the country [35,36]. According to Moswetsi et al. [37], it alone produces more than $30 \%$ of the total maize production in the country and most of its agricultural production (approximately $90 \%$ ) is under rainfed cropping systems [35,36,38].

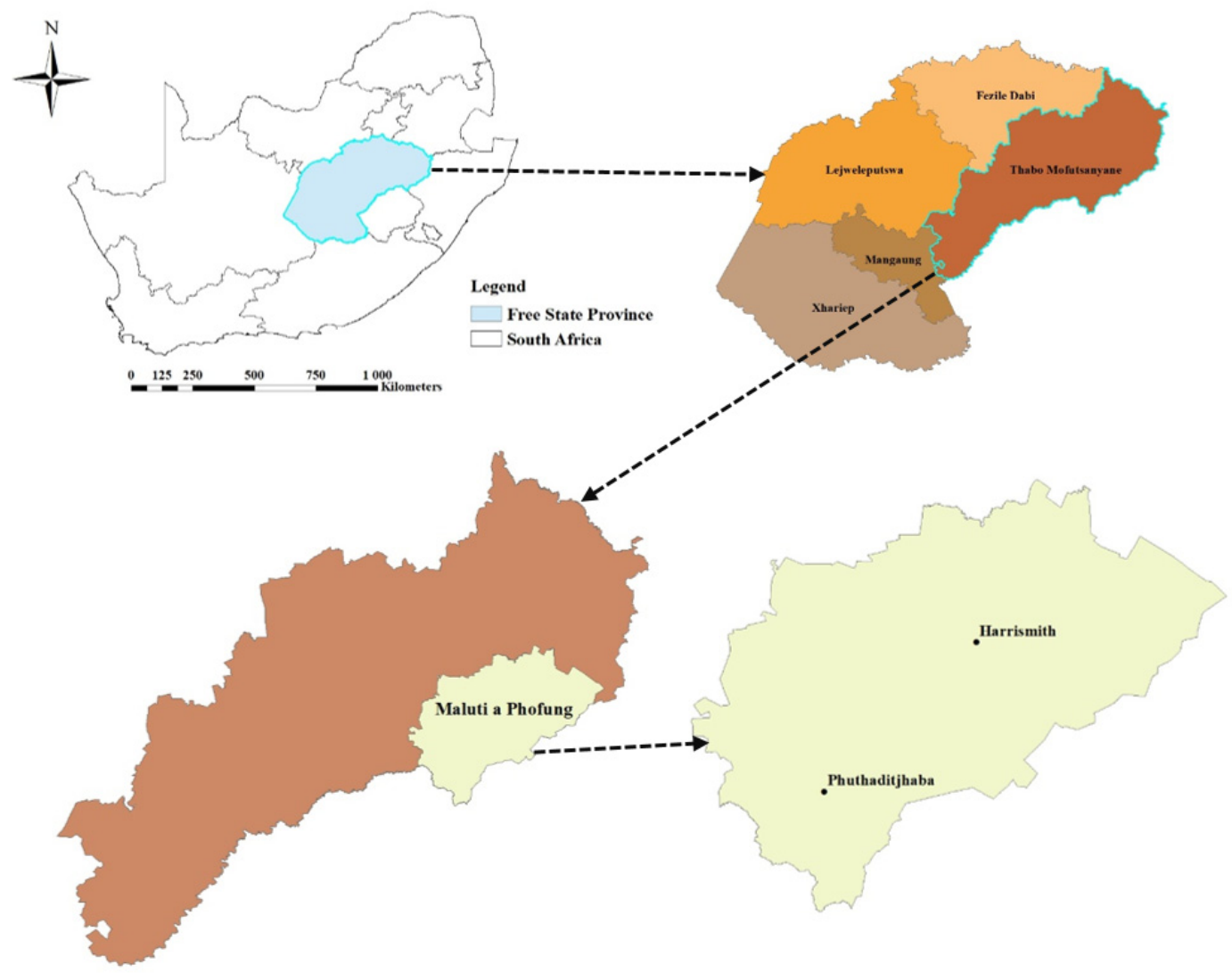

Figure 1. Location of the study area [39]. 
The Maluti-a-Phofung municipality has a subtropical highland climate with a mean annual air temperature of $17^{\circ} \mathrm{C}$ and a mean annual rainfall ranging between 500 and $900 \mathrm{~mm}$ [38]. This area receives most of its rainfall in the summer months (December to February) and often in the form of thunderstorms [39]. The region has a high spatial rainfall variability that is attributed to orographic patterns [35-37]. The summers are characterized by humid and hot days with air temperatures exceeding $30^{\circ} \mathrm{C}$, while the winters are cold and dry with air temperatures below $11^{\circ} \mathrm{C}$ which may decrease to below $0{ }^{\circ} \mathrm{C}$ in June and July months [36].

Droughts and frost occurrence are the major climatic risks that affect agricultural production in this area $[35,36,38,40]$. The high reliance of this region on rainfed agricultural production makes it more sensitive to the adverse effects of climate variability such as decreasing rainfall amounts, altered rainfall distribution and elevated air temperatures that have been already witnessed and are expected to advance $[34,38,40]$. Therefore, the need for adoption of adaptation strategies is critical to build climate-resilient farming communities, improve crop yields, food security and alleviate poverty as the potential effects of climate change continue to threaten the sustainability of agricultural production in this region.

\subsection{Data Collection}

Data for this study were collected from the smallholder farmers in different villages around the Harrismith and Phuthaditjhaba towns as part of the baseline datasets of the InnovAfrica project. InnovAfrica is a multi-disciplinary project that is funded by the European Union's H2020 research and innovation programme and is carried out across six African countries, including South Africa. This on-going project aims to improve the food and nutritional security of smallholders in Africa by integrating sustainable agricultural practices, innovative institutional approaches with novel extension and advisory services. The objective of the project is to strengthen the climate adaptive capacity of smallholders in Africa, improve their productivity, profitability, and nutritional benefits while at the same time reducing adverse environmental impacts.

Primary data were collected by the Agricultural Research Council (ARC) of South Africa in the year 2018 using the pre-tested, structured household questionnaire developed by the Kenya Agricultural \& Livestock Research Organization (KALRO). The demographic and socio-economic characteristics of the household head such as age, gender, occupation, level of education, monthly income, farm size, ownership of farm equipment and livestock, access to media, hired labour, extension services, credit and farmer associations, as well as their perception of the effects of climate change and their adaptation strategies were investigated. The KIPUS software of Knowledge Intelligence Applications $\mathrm{GmbH}$ (KIAG) was used for data capturing and online storage.

Data were collected using a systematic random sampling technique, purposely pursuing smallholder farmers in the villages around the Harrismith and Phuthaditjhaba towns [39]. The selection of a representative sample of farmers was based on the list provided by local extension officers from the Free State Department of Agriculture and Rural Development for each ward, as well as all smallholder farmers from each village who had active backyard gardens and were keen to participate in the household survey voluntary [39]. Before data collection commenced, ten graduates from the study area who had at least a National Diploma in Agriculture or related fields were appointed and trained as enumerators to collect data used for this study. A total of 600 smallholder farmers were interviewed across the different villages. Data collected from the household survey were compiled in a Microsoft Excel spreadsheet and underwent a cleaning process to identify and remove incomplete and suspicious data. As part of data validation, focus group discussion meetings were held with key informants, representing different stakeholders such as the local extension officers, traditional leadership, farmer's association, and smallholder farmers who were beneficiaries of the InnovAfrica project. After the data cleaning process, a total of 391 questionnaires of good quality data were retained for further data analysis. 


\subsection{Data Analysis}

Primary data collected from the household survey were coded by allocating an arithmetical value for easier statistical analysis. The Statistical Package for the Social Sciences (SPSS) version 23.0 was used for data processing and statistical analysis. The demographic and socio-economic characteristics of the smallholder farmers were analysed using descriptive statistics. The perceived impacts of climate change and the adaptation strategies used by smallholder farmers in the study were analysed using the frequency analysis. The frequency analysis has been used in previous similar studies to investigate the farmers' perception of the effects of climate change [5,27].

A binary logistic regression model, with the dependent variable (adoption of either traditional or scientific adaptation strategies) against demographic and socio-economic characteristics of the household as the explanatory variables was used to investigate the factors determining the adoption of the adaptation strategies (Table 1). Explanatory variables were selected based on the literature [5,18,19,41,42]. A detailed description of the explanatory variables was provided by Myeni et al. [39].

Table 1. Description of the explanatory variables used in a binary logistic regression model and expected outcomes.

\begin{tabular}{|c|c|c|c|c|}
\hline \multirow[t]{2}{*}{ Independent Variables } & \multirow[t]{2}{*}{$\begin{array}{l}\text { Description and } \\
\text { Measurement Type }\end{array}$} & \multirow[t]{2}{*}{ Variable Type } & \multicolumn{2}{|c|}{ Expected Outcome $(+/-)$} \\
\hline & & & Traditional & Scientific \\
\hline Gender & Male $(1 / 0)$ & dummy & + & + \\
\hline Age & Age of the farmer (years) & continuous & + & - \\
\hline Level of education & Level of education (years) & continuous & 0 & + \\
\hline Occupation & Own or family farming $(1 / 0)$ & dummy & + & + \\
\hline Off-farm income & $\begin{array}{l}\text { Household off-farm } \\
\text { income (Rands) }\end{array}$ & continuous & 0 & + \\
\hline On-farm income & $\begin{array}{l}\text { Household on-farm } \\
\text { income (Rands) }\end{array}$ & continuous & 0 & + \\
\hline Access to climate information & Access to climate information $(1 / 0)$ & dummy & + & + \\
\hline Ownership of farm equipment & $\begin{array}{c}\text { Ownership of farm } \\
\text { equipment }(1 / 0)\end{array}$ & dummy & + & + \\
\hline Farm size & Land size of arable land (ha) & continuous & - & - \\
\hline Access to hired labour & Access to hired labour (1/0) & dummy & + & + \\
\hline Ownership of livestock & Ownership of livestock (1/0) & dummy & + & + \\
\hline $\begin{array}{c}\text { Awareness of } \\
\text { adaptation strategies }\end{array}$ & $\begin{array}{c}\text { Awareness of } \\
\text { adaptation strategies (1/0) }\end{array}$ & dummy & + & + \\
\hline Access to extension services & Access to extension services $(1 / 0)$ & dummy & + & + \\
\hline Access to credit & Access to credit $(1 / 0)$ & dummy & 0 & + \\
\hline Access to farmer associations & Access to farmer associations $(1 / 0)$ & dummy & + & + \\
\hline
\end{tabular}

$(+/-)$ indicates a positive or negative correlation with the dependent variable. Zero indicates no correlation with the dependent variable.

Responses on the dependent variable were characterized into two categories, i.e., traditional adaptation strategies and scientific adaptation strategies. The traditional adaptation strategies involved practices such as changing from crops to livestock, crop diversification, increasing land under production, changing crop type and water harvesting, while the scientific adaptation strategies involved practices such as changing crop variety, improving soil fertility and soil conservation, which were not common in the study area. The response on the dependent variable traditional adaptation strategies was whether or not the farmer had adopted at least two relevant practices to cope with climate variability, whilst for the dependent variable scientific adaptation strategies, the response was whether or not the farmer had adopted at least two of those practices to cope with climate variability. The binary logit model is more suitable in this case because the response on the dependent variable was either that a farmer had adopted or not adopted either traditional or scientific strategies. The binary logit model has been used in previous similar studies to investigate the relationship between a binary dependent variable and numerical explanatory variables [43-46]. 


\section{Results and Discussion}

\subsection{Summary of Demographic and Socio-Economic Characterization of Smallholder Farmers}

Data obtained from the household survey on the demographic and socio-economic characteristics of smallholder farmers are presented in Table 2 . The results indicate that $52 \%$ of the farms were headed by men and that $41 \%$ of farmers were between $52-66$ years while only $6 \%$ of farmers were youth (<35 years). The majority of smallholder farmers had limited education with $36 \%$ having accomplished secondary education, $30 \%$ had no formal education while only $3 \%$ had attained tertiary education. Furthermore, the study indicated that the main occupation of the majority of the household heads (73\%) was their own or family farming while only $7 \%$ were either self-employed or employed for farming. The study also showed that the majority of smallholder farmers (82\%) were not making any income from their farms, 10\% were earning between ZAR 10.00-500.00 (USD 0.65-32.57) per month, while only $2 \%$ were earning above ZAR 2000.00 (USD 130.28). These findings suggested that the majority of the smallholder farmers were only producing for subsistence purposes in the study area. Furthermore, the results revealed that the majority $(62 \%)$ of the smallholder farmers had limited off-farm income and were earning between ZAR 1010.00-2000.00 (USD 65.79-130.28) per month, while only 1\% were earning above ZAR 10,000.00 (USD 651.41). These findings suggest that off-farm income from either old age or child-support social grants was the major source of income for the majority of the households, as also reported by [41]. Furthermore, the study revealed that most of the farmers had access to media, with the main sources owned by farmers being television (84\%) and radio (73\%), while only $4 \%$ owned computers. The study also suggested that the majority of the farmers had limited access to farm equipment with the most equipment they owned being irrigation equipment $(18 \%)$, water tanks $(9 \%)$ and tractors ( $2 \%)$, while only $1 \%$ owned a spray pump. The majority $(66 \%)$ of smallholder farmers owned between $0.5-1$ ha of land while only $5 \%$ owned more than 2 ha. The majority of farmers $(86 \%)$ also had no access to hired labour, probably due to financial constraints. The results suggested that crop production was the core agricultural activity for smallholder farmers in the study area while only $18 \%$ of the farmers also owned livestock, as also reported by [39]. Furthermore, the results suggested that most of the smallholder farmers (99\%) do not have access to extension services, credit, and farmer associations in the study area. These findings are in agreement with previous studies that had revealed that the majority of South African smallholder farmers have poor access to extension services [47-49], credit [50,51], and farmer associations [7,49,52].

Table 2. Demographic and socio-economic characteristics of smallholder farmers $(n=391)$.

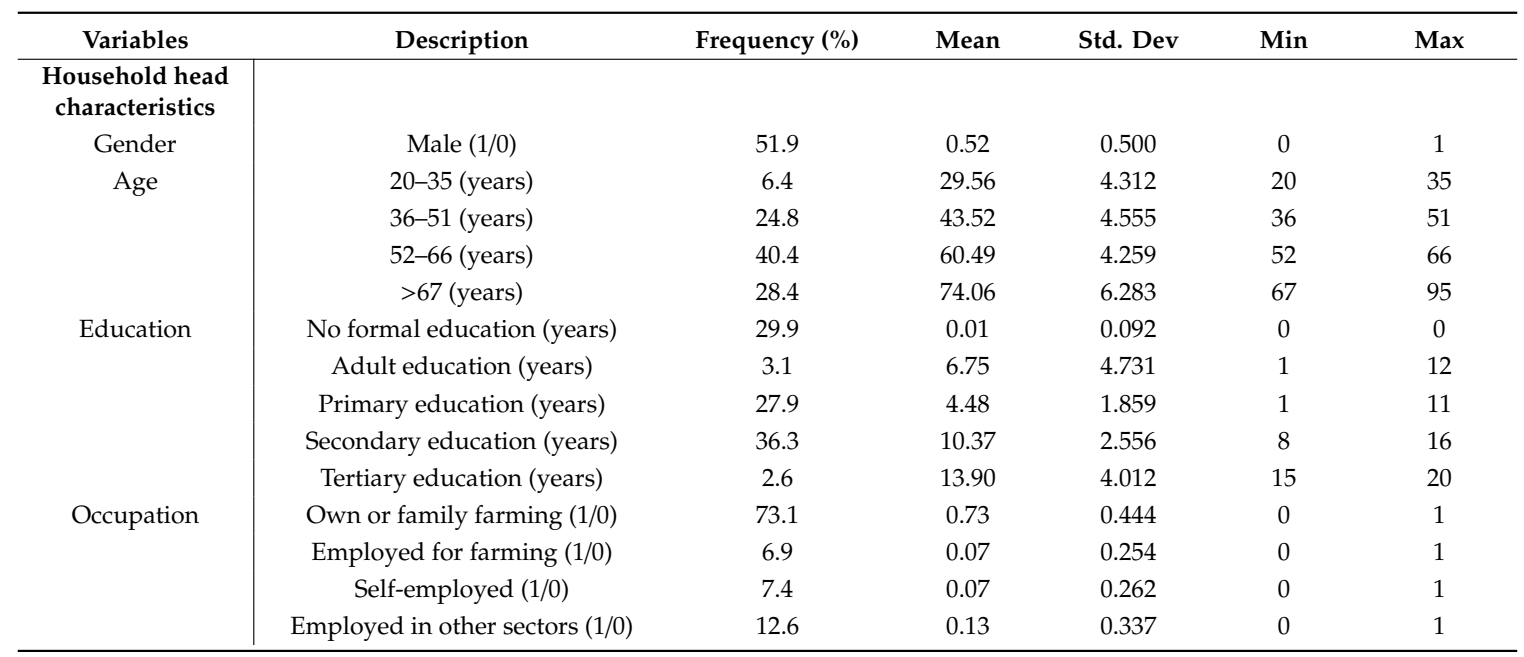


Table 2. Cont.

\begin{tabular}{|c|c|c|c|c|c|c|}
\hline Variables & Description & Frequency (\%) & Mean & Std. Dev & Min & Max \\
\hline \multirow{4}{*}{$\begin{array}{l}\text { Monthly on-farm } \\
\text { income }\end{array}$} & 0 (ZAR) & 81.6 & 0.00 & 0.000 & 0 & 0 \\
\hline & 10-500 (ZAR) & 10.0 & 300.26 & 130.495 & 100 & 500 \\
\hline & 5010-2000 (ZAR) & 6.9 & 1403.70 & 426.508 & 600 & 2000 \\
\hline & >2000 (ZAR) & 1.5 & 2740.00 & 428.019 & 2400 & 3500 \\
\hline \multirow[t]{6}{*}{$\begin{array}{l}\text { Monthly off-farm } \\
\text { income }\end{array}$} & $<500$ (ZAR) & 6.6 & 117.69 & 181.490 & 0 & 460 \\
\hline & 500-1000 (ZAR) & 12.8 & 730.60 & 178.239 & 500 & 1000 \\
\hline & 1010-2000 (ZAR) & 61.9 & 1639.95 & 145.547 & 1140 & 2000 \\
\hline & 2010-5000 (ZAR) & 15.1 & 3335.93 & 707.612 & 2080 & 5000 \\
\hline & 5010-10,000 (ZAR) & 2.8 & 6818.18 & 1270.290 & 5500 & 9000 \\
\hline & $>10,000$ (ZAR) & 0.8 & $14,000.00$ & 2645.751 & 11,000 & 16,000 \\
\hline \multirow[t]{3}{*}{ Media } & Television $(1 / 0)$ & 83.6 & 0.84 & 0.416 & 0 & 1 \\
\hline & Radio (1/0) & 73.1 & 0.73 & 0.455 & 0 & 1 \\
\hline & Computer (1/0) & 4.1 & 0.04 & 0.211 & 0 & 1 \\
\hline \multirow[t]{4}{*}{$\begin{array}{c}\text { Farm equipment } \\
\text { owned }\end{array}$} & Irrigation equipment $(1 / 0)$ & 18.4 & 0.18 & 0.395 & 0 & 1 \\
\hline & Tractor $(1 / 0)$ & 2.3 & 0.02 & 0.150 & 0 & 1 \\
\hline & Spray pump (1/0) & 0.8 & 0.01 & 0.087 & 0 & 1 \\
\hline & Water tanks $(1 / 0)$ & 9.4 & 0.09 & 0.293 & 0 & 1 \\
\hline \multirow[t]{4}{*}{ Total area owned } & $<0.5$ (ha) & 21.0 & 0.38 & 0.06 & 0.25 & 0.49 \\
\hline & $0.5-1$ (ha) & 66.0 & 0.81 & 0.23 & 0.5 & 1 \\
\hline & $1.1-2.0$ (ha) & 8.4 & 1.62 & 0.32 & 1.2 & 2 \\
\hline & $>2$ (ha) & 4.6 & 3.49 & 0.85 & 2.2 & 6.1 \\
\hline Hired labour & Hired labour (1/0) & 13.8 & 0.14 & 0.345 & 0 & 1 \\
\hline $\begin{array}{l}\text { Ownership of } \\
\text { livestock }\end{array}$ & Ownership of livestock $(1 / 0)$ & 18.4 & 0.18 & 0.388 & 0 & 1 \\
\hline Extension services & Access to extension services $(1 / 0)$ & 0.8 & 0.01 & 0.087 & 0 & 1 \\
\hline Credit & Access to credit $(1 / 0)$ & 1.0 & 0.01 & 0.101 & 0 & 1 \\
\hline $\begin{array}{c}\text { Farmer } \\
\text { associations }\end{array}$ & Access to farmer associations $(1 / 0)$ & 0.8 & 0.01 & 0.087 & 0 & 1 \\
\hline
\end{tabular}

\subsection{Farmers' Perception and Adaptation to Climate Change}

\subsubsection{Farmers' Perception of Climate Change}

\section{Farmers' Perception of the Effects of Climate Change}

Awareness of the effects of climate change is the main prerequisite for smallholder farmers to adopt adaptation strategies to offset the negative impacts of climate change/variability on agricultural productivity [53]. Data obtained from the household survey on farmers' perceptions of the effects of climate change are presented in Table 3. Results indicate that smallholder farmers perceived that climate change had caused the decline in crop yield (49\%), food price increase (36\%), food shortage/insecurity $(29 \%)$ and loss of the entire crop $(24 \%)$, while less than $6 \%$ of the farmers perceived the death of livestock and loss of assets as the major impacts of climate change in the study area. These findings suggest that the majority of the smallholder farmers who were aware of the effects of climate change perceived that climate change had caused food-related impacts in the study area. The low perceived effects of climate change on the loss of assets and the death of livestock could be attributed to low ownership of assets and livestock in the study area [39]. 
Table 3. Farmers' perception of the effects of climate change $(n=391)$.

\begin{tabular}{c|cc}
\hline Weather Impacts & Frequency & Percentage (\%) \\
\hline Loss of assets & 22 & 5.6 \\
Loss of entire crop & 93 & 23.8 \\
Food price increase & 141 & 36.1 \\
Loss of income & 43 & 11.0 \\
Death of livestock & 16 & 4.1 \\
Food shortage/insecurity & 112 & 28.6 \\
The decline in crop yield & 191 & 48.8 \\
\hline
\end{tabular}

Farmers' Perception of the Problems Attributed to Climate Change

Data obtained from the household survey on farmers' perceptions of the problems attributed to climate change are presented in Table 4 . The results indicate that most smallholder farmers $(72 \%)$ perceived that climate change had triggered droughts while only $2 \%$ of the farmers perceived that climate change had increased disease incidence in the study area. The perceived frequent occurrence of droughts by smallholder farmers is in agreement with the scientific evidence that drought is the major agro-climatological hazard that threatens the sustainability of agricultural production in the eastern Free State $[34,40,54]$. Furthermore, the results of this study suggest low awareness of the other problems caused by climate change in the study area except only the frequent occurrence of droughts.

Table 4. Farmers' perception of problems attributed to climate change $(n=391)$.

\begin{tabular}{c|cc}
\hline Weather Problems & Frequency & Percentage (\%) \\
\hline Flooding & 46 & 11.8 \\
Drought & 280 & 71.6 \\
Erratic rainfall pattern & 82 & 21.0 \\
Hailstorms & 40 & 10.2 \\
Increased insects and pests & 27 & 6.9 \\
Increased disease incidence & 8 & 2.0 \\
\hline
\end{tabular}

\subsubsection{Adaptation Strategies Used by Smallholder Farmers to Cope with Climate Variability}

About $77 \%$ of the smallholder farmers perceived that weather has changed in the study area over the past 10 years, suggesting a high level of awareness of climate change. Furthermore, the results indicate that most smallholder farmers $(76 \%)$ had adopted at least one adaptation strategy in the study area, with only $24 \%$ having undertaken no adaptation strategy. These findings agreed with the previous studies that reported that the majority of smallholder farmers $(>70 \%)$ had adopted at least one strategy to cope with climate change/variability in Africa [46,55]. The results further revealed that water harvesting (51\%), change of crop variety (47\%), soil conservation (46\%) and improved soil fertility $(28 \%)$ were the most common practices used by smallholder farmers to cope with climate variability in the study area, while increased land under production $(18 \%)$, diversified crops $(15 \%)$, change of crop type (11\%) and change from crop to livestock production (5\%) were the least adopted practices (Table 5). The discussions during the focus group meetings revealed that high preference for water harvesting and change of crop variety strategies were attributed to the effectiveness of these strategies to cope with the effects of droughts that were frequently occurring in the study area. The findings of this study agreed with the findings of Gandure et al. [34], who reported that rainwater harvesting was the most popular adaptation strategy used by smallholder farmers at Thaba Nchu in the eastern Free State. The relatively low adoption of improved soil fertility $(28 \%)$ could be attributed to the high cost of liming or fertilizers, such that the majority of the smallholder farmers cannot afford it as a result of financial constraints and poor access to capital [39]. This study also suggested a low 
adoption of crop diversification and changing crop type, despite the effectiveness and feasibility of these traditional strategies in offsetting the negative effects of climate variability on crop production without any additional technical, labour and financial inputs in resource-constrained communities. Furthermore, the discussions during the focus group meetings revealed that low preference for these traditional adaptation strategies could be attributed to the persisting lack of awareness of the effective and feasible adaptation strategies in the study area. The findings of this study agreed with previous studies that reported the low adoption of traditional strategies across African countries $[18,20,21]$.

Table 5. Strategies used by smallholder farmers to cope with climate variability $(n=391)$.

\begin{tabular}{c|cc}
\hline Adaptation Strategies & Frequency & Percentage (\%) \\
\hline No adaptation strategy used & 92 & 23.5 \\
Change of crop variety & 184 & 47.1 \\
Change from crop to livestock production & 19 & 4.9 \\
Diversified crops & 58 & 14.8 \\
Improve soil fertility & 109 & 27.9 \\
Increased land under production & 70 & 17.9 \\
Soil conservation & 179 & 45.8 \\
Water harvesting & 198 & 50.6 \\
Change of crop type & 46 & 11.8 \\
\hline
\end{tabular}

\subsection{Factors Determining the Adoption of Adaptation Strategies Used by Smallholder Farmers}

\subsubsection{Factors Determining the Adoption of Traditional Adaptation Strategies by Smallholder Farmers}

Results obtained from a binary logistic regression model indicated that on-farm income $(p<0.05)$, access to climate information $(p<0.1)$, and awareness of traditional adaptation strategies $(p<0.01)$ were the main variables that had a significant influence on the adoption of traditional adaptation strategies by smallholder farmers in the study area (Table 6).

Table 6. Estimated results on the factors determining the adoption of traditional adaptation strategies.

\begin{tabular}{c|ccccc}
\hline Explanatory Variables & Coefficients & Odds Ratios & Std. Err. & $z$ & 0.008 \\
Gender & 0.024 & 1.024 & 0.269 & 0.929 \\
Age & 0.001 & 1.001 & 0.012 & 0.014 & 0.905 \\
Level of education & 0.027 & 1.027 & 0.036 & 0.573 & 0.449 \\
Occupation & -0.021 & 0.979 & 0.331 & 0.004 & 0.948 \\
Off-farm income & 0.000 & 1.000 & 0.000 & 0.558 & 0.455 \\
On-farm income & $0.001 * *$ & 1.001 & 0.000 & 4.203 & 0.040 \\
Access to climate information & $-0.445 *$ & 0.641 & 0.267 & 2.774 & 0.096 \\
Ownership of farm equipment & -1.366 & 0.255 & 0.858 & 2.534 & 0.111 \\
Farm size & -0.010 & 0.990 & 0.215 & 0.002 & 0.961 \\
Access to hired labour & -0.282 & 0.754 & 0.413 & 0.467 & 0.494 \\
Ownership of livestock & 0.063 & 1.065 & 0.362 & 0.030 & 0.861 \\
Awareness of adaptation strategies & $2.887 * * *$ & 17.948 & 0.418 & 47.816 & 0.000 \\
Access to extension services & 2.292 & 9.894 & 1.631 & 1.976 & 0.160 \\
Access to credit & -1.955 & 0.142 & 1.500 & 1.698
\end{tabular}

Std. Err. is the Standard Error in parentheses $\left({ }^{*} p<0.1{ }^{* *} p<0.05^{* *} p<0.01\right)$. 


\subsubsection{Factors Determining Adoption of Scientific Adaptation Strategies by Smallholder Farmers}

Results obtained from a binary logistic regression model indicated that farm size $(p<0.05)$, ownership of livestock $(p<0.1)$, awareness of scientific adaptation strategies $(p<0.01)$, and access to credit $(p<0.1)$ were the main variables that had a significant influence on the adoption of scientific adaptation strategies by smallholder farmers in the study area (Table 7).

Table 7. Estimated results on the factors influencing the adoption of scientific adaptation strategies.

\begin{tabular}{c|ccccc}
\hline Explanatory Variables & Coefficients & Odds Ratios & Std. Err. & $z$ & $p>z$ \\
Gender & 0.075 & 1.077 & 0.306 & 0.060 & 0.807 \\
Age & -0.006 & 0.994 & 0.014 & 0.191 & 0.662 \\
Level of education & -0.010 & 0.990 & 0.041 & 0.058 & 0.810 \\
Occupation & 0.237 & 1.268 & 0.384 & 0.381 & 0.537 \\
Off-farm income & 0.000 & 1.000 & 0.000 & 0.028 & 0.868 \\
On-farm income & 0.000 & 1.000 & 0.000 & 1.328 & 0.249 \\
Access to climate information & 0.130 & 1.139 & 0.306 & 0.180 & 0.671 \\
Ownership of farm equipment & 0.189 & 1.209 & 0.731 & 0.067 & 0.796 \\
Farm size & $-0.610 * *$ & 0.543 & 0.303 & 4.045 & 0.044 \\
Access to hired labour & 0.455 & 1.576 & 0.431 & 1.114 & 0.291 \\
Ownership of livestock & $0.737^{*}$ & 2.089 & 0.389 & 3.580 & 0.058 \\
Awareness of adaptation strategies & $4.231^{* * *}$ & 68.761 & 1.018 & 17.260 & 0.000 \\
Access to extension services & -1.604 & 0.201 & 1.841 & 0.759 & 0.384 \\
Access to credit & $2.793 *$ & 16.335 & 1.474 & 3.592 & 0.058 \\
Access to farmer associations & 2.075 & 7.967 & 1.510 & 1.888 & 0.169 \\
& & Number of observations $=391$ &
\end{tabular}

Std. Err. is the Standard Error in parentheses $\left({ }^{*} p<0.1{ }^{* *} p<0.05^{* * *} p<0.01\right)$.

\subsubsection{Overall Discussion}

In this section, brief discussions of the explanatory variables that had a significant effect on the adoption of either traditional or scientific adaptation strategies used by smallholder farmers to cope with climate variability in the study area are provided.

\section{On-Farm Income}

The effect of the variable on-farm income had a positive and significant influence (0.001) only on the adoption of traditional practices used by smallholder farmers in the study area. For a unit increase in on-farm income, the odds of a farmer adopting traditional adaptation strategies are 1.001. The results suggest that farmers who sell their produce were more likely to adopt traditional adaptation strategies than their counterparts. The possible explanation for this is that farmers who are selling their produce are making their living from crop production, hence sustaining their production was their top priority. Consequently, farmers who were selling their produce were more enthusiastic to optimize their indigenous knowledge and the resources they had for optimal crop production under the threat of climate change.

\section{Access to Climate Information}

The variable access to climate information had a negative and significant effect $(-0.445)$ only on the adoption of traditional adaptation practices used by smallholder farmers in the study area. For a unit increase in access to climate information, the odds of a farmer adopting traditional adaptation strategies are 0.641 . Unexpectedly, the results suggest that smallholder farmers with access to climate information were less likely to adopt traditional adaptation strategies. During the focus group discussions, it was discovered that the majority of farmers had access only to the daily weather forecast from either radio or television and very few had access to medium-term or seasonal forecasts. This climate information is unreliable and does not provide farmers with any recommendations on management practices. 
Furthermore, the focus group discussions also revealed that the majority of smallholder farmers had no access to early warning systems and information on rainfall distribution throughout the season which could help them to plan better and make informed decisions on crop management to minimize the impacts of weather-related risks [42,56,57]. The poor access to relevant, timely, and reliable climate information hindered the farmers' adoption of the traditional practices as a result of uncertainties and lack of confidence in their indigenous knowledge, which has become more unreliable as climate variability intensifies. Therefore, the need for the provision of meaningful, reliable and local-specific climate information so that farmers can have confidence in making their decisions regarding crop choices, planting dates and adaptation strategies cannot be overemphasized $[27,29,42,58,59]$.

Awareness of Adaptation Strategies

Awareness of adaptation strategies was the main factor that had a positive and significant effect on the adoption of both traditional adaptation strategies (2.887) and scientific adaptation strategies (4.231) used by smallholder farmers in the study area. For a unit increase in the variable awareness of adaptation strategies, the odds of a farmer adopting them are 17.948 for traditional adaptation strategies and 68.761 for scientific adaptation strategies. The results suggest that knowledge and awareness were the main prerequisites for smallholder farmers to be able to adopt adaptation strategies in the study area. The findings of this study are in agreement with previous studies that showed that knowledge and awareness were the main variables determining the adoption of adaptation strategies by smallholder farmers in Africa [6,29,60,61]. Focus group discussions revealed the low awareness of the feasible adaptation strategies in the study area, although some smallholder farmers were already practising these strategies without knowing their effectiveness in building a climate-resilience farming community. The lack of awareness could be attributed to the low level of education and poor access to extension services in the study area which hindered the smallholder farmers from reading and understanding the climate information as well as the relative, feasible and effective adaptation strategies [39]. Consequently, the lack of awareness of adaptation strategies, if not addressed at a high priority level, is more likely to hinder smallholder farmers in the study area from adopting strategies to cope with climate variability. These findings suggest that targeting policies and interventions that aim to raise awareness of climate change and relative adaptation strategies alone can significantly improve the climate resilience of the smallholder farmer in the study area.

\section{Farm Size}

Variable farm size had a negative and significant effect $(-0.610)$ only on the adoption of scientific practices used by smallholder farmers in the study area. For a unit increase in farm size, the odds of a farmer adopting scientific adaptation strategies are 0.543 , suggesting that those with larger farm sizes were less likely to adopt scientific adaptation strategies, probably due to the labour-intensiveness and resource-intensiveness of the strategies. Thus, large farms require significant financial investments on labour and inputs, which is currently financially unattainable in the study area. These findings agreed with previous studies that reported that farm size had a negative influence on the adoption of the adaptation strategies by smallholder farmers [18,19,28,59,62].

\section{Ownership of Livestock}

The results showed that ownership of livestock had a positive and significant influence (0.737) only on the adoption of scientific practices used by smallholder farmers in the study area. For a unit increase in the variable ownership of livestock, the odds of a farmer adopting scientific adaptation strategies are 2.089, suggesting that those who own livestock were more likely to adopt scientific adaptation strategies. The possible explanation for this is that farmers owning livestock can generate extra income from their sales to hire labour and also purchase inputs such as fertilizers and hybrid seeds that are required for scientific adaptation strategies. Furthermore, farmers possessing livestock were more likely to adopt practices that have the potential to increase their crop production to improve 
feed security for their livestock [39]. The findings of this study agreed with previous studies that reported a positive influence of livestock ownership on the adoption of the adaptation strategies by smallholder farmers $[59,62]$.

\section{Access to Credit}

The results showed that access to credit significantly and positively (0.737) affected only the adoption of scientific adaptation strategies used by smallholder farmers in the study area. For a unit increase in the variable access to credit, the odds of a farmer adopting scientific adaptation strategies are 16.335 , suggesting that those who had access to credit were more likely to adopt scientific adaptation strategies. The possible explanation for this is that access to credit offsets financial constraints and thus enables the farmer to hire labour and purchase inputs such as improved crop variety and fertilizers required for scientific adaptation strategies. These findings are in agreement with previous studies that reported that access to credit significantly and positively influences the adoption of scientific adaptation strategies by smallholder farmers $[6,18,27,29]$.

\section{Conclusions and Recommendations}

Climate change/variability is already and is likely to continue affecting agricultural productivity negatively in Africa where the majority of the smallholder farmers are reliant mainly on rainfed crop production for their livelihoods and household food security. This study was undertaken to understand the smallholder farmer's perception of the effects of climate change, their adaptation strategies, and factors determining the adoption of their adaptation strategies in the eastern Free State Province of South Africa. The results showed that most of the smallholder farmers who were aware of the impacts of climate change perceived that climate change had caused food-related impacts such as a decline in crop yield, food price increase, food shortage/insecurity, and loss of the entire crop. The study further showed that the majority of the smallholder farmers had adopted at least one practice to cope with climate variability in the study area. Water harvesting, changing crop variety, soil conservation, and improving soil fertility were the most popular adaptation strategies used by smallholder farmers in the study area while increasing land under crop production, crop diversification, changing crop type, and changing from crop to livestock production were the least used practices.

Results indicated that on-farm income and awareness of traditional adaptation strategies were the main factors that significantly and positively influence the adoption of traditional adaptation strategies, while access to climate information had a significant and negative effect on their adoption. Furthermore, the study indicates that ownership of livestock, awareness of scientific adaptation strategies and access to credit were the key factors that significantly and positively influence the adoption of scientific adaptation strategies, while farm size had a significant and negative effect on their adoption. The study showed that awareness and knowledge were the key factors influencing the adoption of traditional adaptation strategies in the study area while scientific adaptation strategies were additionally influenced by the availability of additional financial investments. The findings suggest that interventions that aim to raise climate change awareness alone can significantly improve the adoption of traditional adaptation strategies. Therefore, awareness-raising of climate change and relative adaptation strategies through training, education and field days is recommended for wider adoption of the adaptation strategies. Furthermore, interventions and policies that enhance the access of smallholder farmers to financial institutional support and incentives are recommended for wider adoption of scientific adaptation strategies.

The findings of this study suggest that, in order to enhance climate-resilience with minimal external inputs, the promotion of traditional adaptation strategies that are feasible to these resource-constrained smallholder farmers is critical. Therefore, it is recommended that interventions and policies aiming to strengthen the climate adaptive capacity of smallholders should concentrate on promoting the adoption of traditional adaptation strategies such as changing from crops to livestock, crop 
diversification, increasing land under production, changing crop type, water harvesting, and planting dates through awareness-raising.

Availability and accessibility of relevant, timely and reliable climate information enable the farmers to plan effectively and make informed decisions on adaptation strategies to be used, and hence build climate-resilient farming communities. However, the lack of awareness of climate change and adaptation strategies, as well as poor access to climate information, are the key knowledge-related barriers hindering smallholder farmers from coping effectively with climate variability in the study area. This lack of knowledge could be attributed too poor access to extension services, which are assigned to provide smallholder farmers with technical advisories on climate information, adaptation strategies and sustainable agricultural practices as well as information on credit and market facilities. Therefore, it is recommended that the quality and outreach of extension services in the study area is improved through capacity building and provision of resources as well as relevant, timely and reliable climate information.

Author Contributions: Conceptualization, L.M. and M.E.M.; methodology, L.M. and M.E.M.; software, L.M.; validation, L.M.; formal analysis, L.M.; writing — original draft preparation, L.M.; writing-review and editing, L.M. and M.E.M. All authors have read and agreed to the published version of the manuscript.

Funding: This research was funded by the European Union's H2020 research and innovation programme, Grant Agreement No. 727201.

Acknowledgments: The InnovAfrica project (http://www.innovafrica.eu/) is gratefully acknowledged for the provision of data. Knowledge Intelligence Applications $\mathrm{GmbH}$ (KIAG) is gratefully acknowledged for the provision of KIPUS software and Kenya Agricultural \& Livestock Research Organization (KALRO) for the provision of a questionnaire used for primary data collection. Mulalo Thavhana (ARC) is gratefully acknowledged for her technical assistance during data collection. The authors also acknowledge the Free State Department of Agriculture and Rural Development extension officers and smallholder farmers for their time and their active participation in the household survey as well as focus group discussions. The authors also thank Thomas Fyfield (ARC) for editorial assistance.

Conflicts of Interest: The authors declare no conflict of interest.

\section{References}

1. Our Future Make It Work: National Development Plan 2030; NPC: Cape Town, South Africa, 2012. Available online: https:/www.gov.za/sites/default/files/gcis_document/201409/ndp-2030-our-future-make-it-workr. pdf (accessed on 10 February 2020).

2. Von Loeper, W.; Musango, J.; Brent, A.; Drimie, S. Analysing challenges facing smallholder farmers and conservation agriculture in South Africa: A system dynamics approach. S. Afr. J. Econ. Manag. Sci. 2016, 19, 747-773.

3. DAFF. Framework for the Development of Smallholder Farmers throug h Cooperatives Development. DAFF Dep. Agric. For. and Fish. Pretoria. 2012. Available online: http://Www.Nda.Agric.Za/Doadev/Sidemenu/ Cooperativeandenterprisedevelopment/Docs/Framework-\%20of\%20small\%20farmers\%20(2).Pdf (accessed on 28 February 2020).

4. Field, C.B.; Barros, V.; Stocker, T.F.; Dahe, Q. Managing the Risks of Extreme Events and Disasters to Advance Climate Change Adaptation: Special Report of the Intergovernmental Panel on Climate Change; Cambridge University Press: Cambridge, UK, 2012; ISBN 1107025060.

5. Belay, A.; Recha, J.W.; Woldeamanuel, T.; Morton, J.F. Smallholder farmers' adaptation to climate change and determinants of their adaptation decisions in the Central Rift Valley of Ethiopia. Agric. Food Secur. 2017, $6,1-13$.

6. Saguye, T.S. Determinants of Smallholder Farmers' Adoption of Climate Change and Variability Adaptation Strategies: Evidence from Geze Gofa District, Gamo Gofa Zone, Southern Ethiopia. J. Environ. Earth Sci. 2016, 6, 147-161.

7. Thamaga-Chitja, J.M.; Morojele, P. The context of smallholder farming in South Africa: Towards a livelihood asset building framework. J. Hum. Ecol. 2014, 45, 147-155. 
8. Ubisi, N.R.; Mafongoya, P.L.; Kolanisi, U.; Jiri, O. Smallholder farmer's perceived effects of climate change on crop production and household livelihoods in rural Limpopo province, South Africa. Chang. Adapt. Socio-Ecol. Syst. 2017, 3, 27-38. [CrossRef]

9. Calzadilla, A.; Zhu, T.; Rehdanz, K.; Tol, R.S.J.; Ringler, C. Climate change and agriculture: Impacts and adaptation options in South Africa. Water Resour. Econ. 2014, 5, 24-48.

10. IPCC. Climate Change 2014 Part A: Global and Sectoral Aspects [Internet]. Climate Change 2014 Impacts, Aspects Vulnerability. Part A Global and Sectoral Aspects Contribution of Working Group II to Fifth Assessment Report of the Intergovernmental Panel Climate Change. 2014. Available online: papers2://publication/uuid/ B8BF5043-C873-4AFD-97F9-A630782E590D (accessed on 2 February 2020).

11. Mpandeli, S.; Nhamo, L.; Moeletsi, M.; Masupha, T.; Magidi, J.; Tshikolomo, K.; Liphadzi, S.; Naidoo, D.; Mabhaudhi, T. Assessing climate change and adaptive capacity at local scale using observed and remotely sensed data. Weather Clim. Extrem. 2019, 26, 1-13.

12. Knox, J.; Hess, T.; Daccache, A.; Wheeler, T. Climate change impacts on crop productivity in Africa and South Asia. Environ. Res. Lett. 2012, 7, 1-8.

13. Ncube, E.; Flett, B.C.; Waalwijk, C.; Viljoen, A. Fusarium spp. and levels of fumonisins in maize produced by subsistence farmers in South Africa. S. Afr. J. Sci. 2011, 107, 1-7.

14. Tamako, N.; Thamaga-Chitja, J.M. Does social capital play a role in climate change adaptation among smallholder farmers for improving food security and livelihoods? Food Nutr. Chall. S. Afr. 2017, 2, 16-26.

15. Pretty, J.; Toulmin, C.; Williams, S. Sustainable intensification in African agriculture. Int. J. Agric. Sustain. 2011, 9, 5-24. [CrossRef]

16. Yila, J.O.; Resurreccion, B.P. Determinants of smallholder farmers' adaptation strategies to climate change in the semi arid Nguru Local Government Area, Northeastern Nigeria. Manag. Environ. Qual. An. Int. J. 2013, 24, 341-364. [CrossRef]

17. McCarthy, N.; Lipper, L.; Branca, G. Climate-smart agriculture: Smallholder adoption and implications for climate change adaptation and mitigation. Mitig. Clim. Chang. Agric. Work. Pap. 2011, 3, 1-37.

18. Tessema, Y.A.; Joerin, J.; Patt, A. Factors affecting smallholder farmers' adaptation to climate change through non-technological adjustments. Environ. Dev. 2018, 25, 33-42. [CrossRef]

19. Deressa, T.T.; Hassan, R.M.; Ringler, C.; Alemu, T.; Yesuf, M. Determinants of farmers' choice of adaptation methods to climate change in the Nile Basin of Ethiopia. Glob. Environ. Chang. 2009, 19, 248-255. [CrossRef]

20. Waha, K.; Müller, C.; Bondeau, A.; Dietrich, J.P.; Kurukulasuriya, P.; Heinke, J.; Lotze-Campen, H. Adaptation to climate change through the choice of cropping system and sowing date in sub-Saharan Africa. Glob. Environ. Chang. 2013, 23, 130-143. [CrossRef]

21. Shikuku, K.M.; Winowiecki, L.; Twyman, J.; Eitzinger, A.; Perez, J.G.; Mwongera, C.; Läderach, P. Smallholder farmers' attitudes and determinants of adaptation to climate risks in East Africa. Clim. Risk Manag. 2017, 16, 234-245. [CrossRef]

22. Arunrat, N.; Wang, C.; Pumijumnong, N.; Sereenonchai, S.; Cai, W. Farmers' intention and decision to adapt to climate change: A case study in the Yom and Nan basins, Phichit province of Thailand. J. Clean. Prod. 2017, 143, 672-685. [CrossRef]

23. Juana, J.S.; Kahaka, Z.; Okurut, F.N. Farmers' Perceptions and Adaptations to Climate Change in Sub-Sahara Africa: A Synthesis of Empirical Studies and Implications for Public Policy in African Agriculture. J. Agric. Sci. 2013, 5, 121-135. [CrossRef]

24. Simelton, E.; Quinn, C.H.; Batisani, N.; Dougill, A.J.; Dyer, J.C.; Fraser, E.D.G.; Mkwambisi, D.; Sallu, S.; Stringer, L.C. Is rainfall really changing? Farmers' perceptions, meteorological data, and policy implications. Clim. Dev. 2013, 5, 123-138. [CrossRef]

25. Comoé, H. Contribution to Food Security by Improving Farmers' Responses to Climate Change in Northern and Central Areas of Côte D'ivoire 2013. Available online: https://www.research-collection.ethz.ch/handle/ 20.500.11850/69024 (accessed on 23 February 2020).

26. Assoumana, B.T.; Ndiaye, M.; Puje, G.; Diourte, M.; Graiser, T. Comparative assessment of local farmers' perceptions of meteorological events and adaptations strategies: Two Case Studies in Niger Republic. J. Sustain. Dev. 2016, 9, 118-135. [CrossRef]

27. Ndamani, F.; Watanabe, T. Determinants of farmers' adaptation to climate change: A micro level analysis in Ghana. Sci. Agric. 2016, 73, 201-208. [CrossRef] 
28. Deressa, T.T.; Hassan, R.M.; Ringler, C. Perception of and adaptation to climate change by farmers in the Nile basin of Ethiopia. J. Agric. Sci. 2011, 149, 23-31. [CrossRef]

29. Mutunga, E.; Ndungu, C. Muendo Patricia Factors Influencing Smallholder Farmers' Adaptation to Climate Variability in Kitui County, Kenya. Int. J. Environ. Sci. Nat. Resour. 2018, 8, 155-161.

30. Morton, J.F. The impact of climate change on smallholder and subsistence agriculture. Proc. Natl. Acad. Sci. USA 2007, 104, 19680-19685. [CrossRef]

31. Eriksen, S.; Aldunce, P.; Bahinipati, C.S.; Martins, R.D.; Molefe, J.I.; Nhemachena, C.; O’brien, K.; Olorunfemi, F.; Park, J.; Sygna, L. When not every response to climate change is a good one: Identifying principles for sustainable adaptation. Clim. Dev. 2011, 3, 7-20. [CrossRef]

32. Debalke, N.M. Determinants of farmers' preference for adaptation strategies to climate change: Evidence from north shoa zone of Amhara region Ethiopia. Munich Pers RePEc Arch. 2013, 2, 1-12.

33. Maponya, P.; Mpandeli, S. Climate Change and Agricultural Production in South Africa: Impacts and Adaptation options. J. Agric. Sci. 2012, 4, 48-60. [CrossRef]

34. Gandure, S.; Walker, S.; Botha, J.J. Farmers' perceptions of adaptation to climate change and water stress in a South African rural community. Environ. Dev. 2013, 5, 39-53. [CrossRef]

35. Mbiriri, M.; Mukwada, G.; Manatsa, D. Influence of altitude on the spatiotemporal variations of meteorological droughts in mountain regions of the free state Province, South Africa (1960-2013). Adv. Meteorol. 2018, 2018, 1-11. [CrossRef]

36. Moeletsi, M.E.; Walker, S. Agroclimatological suitability mapping for dryland maize production in Lesotho. Theor. Appl. Climatol. 2013, 114, 227-236.

37. Moswetsi, G.; Fanadzo, M.; Ncube, B. Cropping systems and agronomic management practices in smallholder farms in South Africa: Constraints, challenges and opportunities. J. Agron. 2017, 16, 51-64.

38. Botai, C.M.; Botai, J.O.; Dlamini, L.C.; Zwane, N.S.; Phaduli, E. Characteristics of droughts in South Africa: A case study of free state and North West provinces. Water 2016, 8, 1-23.

39. Myeni, L.; Moeletsi, M.; Thavhana, M.; Randela, M.; Mokoena, L. Barriers Affecting Sustainable Agricultural Productivity of Smallholder Farmers in the Eastern Free State of South Africa. Sustainability 2019, 11, 3003.

40. Moeletsi, M.E.; Tongwane, M.; Tsubo, M. The study of frost occurrence in free state province of South Africa. Adv. Meteorol. 2016, 2016, 1-9.

41. Fadina, A.M.R.; Barjolle, D. Farmers' adaptation strategies to climate change and their implications in the Zou department of South Benin. Environments 2018, 5, 1-17.

42. Dang, H.L.; Li, E.; Nuberg, I.; Bruwer, J. Factors influencing the adaptation of farmers in response to climate change: A review. Clim. Dev. 2019, 11, 765-774.

43. Zamasiya, B.; Nyikahadzoi, K.; Mukamuri, B.B. Factors influencing smallholder farmers' behavioural intention towards adaptation to climate change in transitional climatic zones: A case study of Hwedza District in Zimbabwe. J. Environ. Manag. 2017, 198, 233-239.

44. Marie, M.; Yirga, F.; Haile, M.; Tquabo, F. Farmers' choices and factors affecting adoption of climate change adaptation strategies: Evidence from northwestern Ethiopia. Heliyon 2020, 6, 1-10.

45. Kolleh, J.B. Rice Farmers' Perception of Climate Change and Adaptation Strategies in the Ketu North district, Volta Region of Ghana. 2015. Available online: https://academicjournals.org/journal/AJAR/article-abstract/ 62D920456626 (accessed on 25 February 2020).

46. Fagariba, C.J.; Song, S.; Baoro, S.K.G.S. Climate change adaptation strategies and constraints in Northern Ghana: Evidence of farmers in Sissala West District. Sustainability 2018, 10, 1484.

47. Kruger, E.; Gilles, J.L. A Review of Participatory Agricultural Research and Development in South Africa and KwaZulu Natal. 2014. Available online: http://www.mahlathini.org/wp-content/uploads/2016/11/ Participatory-Agricultural-Research-in-SA_final_-12-June-2014.pdf (accessed on 12 February 2020).

48. Diale, N.R. Socio-economic indicators influencing the adoption of hybrid Sorghum: The Sekhukhune District perspective. S. Afr. J. Agric. Ext. 2011, 39, 75-85.

49. Aliber, M.; Hall, R. Support for smallholder farmers in South Africa: Challenges of scale and strategy. Dev. S. Afr. 2012, 29, 548-562.

50. Van Schalkwyk, H.D.; Groenewald, J.A.; Fraser, G.C.G.; Obi, A.; Van Tilburg, A. Unlocking Markets to Smallholders: Lessons from South Africa; Springer Science \& Business Media: Berlin/Heidelberg, Germany, 2012; Volume 10, ISBN 9086861687. 
51. Khapayi, M.; Celliers, P.R. Factors limiting and preventing emerging farmers to progress to commercial agricultural farming in the King William's Town area of the Eastern Cape Province, South Africa. S. Afr. J. Agric. Ext. 2016, 44, 25-41.

52. Pienaar, L.; Traub, L. Understanding the Smallholder Farmer in South Africa: Towards a Sustainable Livelihoods Classification. 2015. Available online: https://ageconsearch.umn.edu/record/212633/files/ Pienaar-Understanding\%20the\%20smallholder\%20farmer\%20in\%20South\%20Africa-1233.pdf (accessed on 10 February 2020).

53. Hassan, R.M.; Nhemachena, C. Determinants of African farmers' strategies for adapting to climate change: Multinomial choice analysis. Afr. J. Agric. Resour. Econ. 2008, 2, 83-104.

54. Moeletsi, M.E.; Walker, S. Rainy season characteristics of the Free State Province of South Africa with reference to rain-fed maize production. Water $S A$ 2012, 38, 775-782.

55. Thoai, T.Q.; Rañola, R.F.; Camacho, L.D.; Simelton, E. Determinants of farmers' adaptation to climate change in agricultural production in the central region of Vietnam. Land Use Policy 2018, 70, 224-231.

56. Maddison, D. The Perception of and Adaptation to Climate Change in Africa; The World Bank: Washington, DC, USA, 2007; Available online: https://elibrary.worldbank.org/doi/pdf/10.1596/1813-9450-4308 (accessed on 15 February 2020).

57. Dinku, T.; Block, P.; Sharoff, J.; Hailemariam, K.; Osgood, D.; Del Corral, J.; Cousin, R.; Thomson, M.C. Bridging critical gaps in climate services and applications in Africa. Earth Perspect. 2014, 1, 1-13.

58. Nhemachena, C.; Hassan, R. Micro-Level Analysis of Farmers' Adaptation to Climate Change in Southern Africa. Centre for Environmental Economics and Policy in Africa (CEEPA) and Rashid Hassan, Centre for Environmental Economics and Policy in Africa (CEEPA). Int. Food Policy Res. Inst. 2007, 1, 1-28.

59. Amare, A.; Simane, B. Determinants of smallholder farmers' decision to adopt adaptation options to climate change and variability in the Muger Sub basin of the Upper Blue Nile basin of Ethiopia. Agric. Food Secur. 2017, 6, 1-20.

60. Mulwa, C.; Marenya, P.; Rahut, D.B.; Kassie, M. Response to climate risks among smallholder farmers in Malawi: A multivariate probit assessment of the role of information, household demographics, and farm characteristics. Clim. Risk Manag. 2017, 16, 208-221.

61. Mashizha, T.M. Adapting to climate change: Reflections of peasant farmers in Mashonaland West Province of Zimbabwe. Jàmbá J. Disaster Risk Stud. 2019, 11, 1-8. [CrossRef]

62. Regmi, N.; Dhakal, D.; Ghimire, B. Determinants of farmers' adaptation to climate change: A case from Syangja district of Nepal. J. Agric. Econ. Ext. Rural Dev. 2017, 5, 658-663. 